\title{
Seasonal trends of dry and bulk concentration of nitrogen compounds over a rain forest in Ghana
}

\author{
F. Fattore ${ }^{1}$, T. Bertolini ${ }^{2}$, S. Materia ${ }^{2}$, S. Gualdi ${ }^{2,4}$, A. Thongo M'Bou ${ }^{2}$, G. Nicolini ${ }^{2,3}$, R. Valentini ${ }^{2,3}$, \\ A. De Grandcourt ${ }^{2}$, D. Tedesco ${ }^{1}$, and S. Castaldi ${ }^{1,2}$ \\ ${ }^{1}$ DiSTABiF, Seconda Università degli Studi di Napoli, Via A. Vivaldi, 43, 81100 Caserta, Italy \\ ${ }^{2}$ CMCC, Via A. Imperatore, 16, 73100, Lecce, Italy \\ ${ }^{3}$ DIBAF, Università della Tuscia, Via San Camillo de Lellis, 01100 Viterbo, Italy \\ ${ }^{4}$ INGV, Via D. Creti, 12, 40128, Bologna, Italy \\ Correspondence to: F. Fattore (fattoreferdinando@gmail.com)
}

Received: 15 August 2013 - Published in Biogeosciences Discuss.: 17 September 2013

Revised: 10 April 2014 - Accepted: 14 April 2014 - Published: 12 June 2014

\begin{abstract}
African tropical forests of the equatorial belt might receive significant input of extra nitrogen derived from biomass burning occurring in the north savanna belt and transported equatorward by northeastern winds. In order to test this hypothesis an experiment was set up in a tropical rain forest in the Ankasa Game Reserve and Nini-Suhien National Park (Ghana) aimed at quantifying magnitude and seasonal variability of concentrations of $\mathrm{N}$ compounds, present as gas and aerosol (dry nitrogen) or in the rainfall (bulk nitrogen), over the studied forest; and relating their seasonal variability to trends of local and regional winds and rainfall and to variations of fire events in the region. Three DELTA systems, implemented for monthly measurements of $\mathrm{NO}_{2}$, were mounted over a tower at $45 \mathrm{~m}$ height, $20 \mathrm{~m}$ above forest canopy to sample gas $\left(\mathrm{NH}_{3}, \mathrm{NO}_{2}, \mathrm{HNO}_{3}, \mathrm{HCl}, \mathrm{SO}_{2}\right)$ and aerosol $\left(\mathrm{NH}_{4}^{+}\right.$, $\mathrm{NO}_{3}^{-}$, and several ions), together with three tanks for bulk rainfall collection (to analyze $\mathrm{NH}_{4}^{+}, \mathrm{NO}_{3}^{-}$and ion concentration). The tower was provided with a sonic anemometer to estimate local wind data. The experiment started in October 2011 and data up to October 2012 are presented. To interpret the observed seasonal trends of measured compounds, local and regional meteo data and regional satellite fire data were analyzed. The concentration of $\mathrm{N}$ compounds significantly increased from December to April, during the drier period, peaking from December to February when NE winds (the Harmattan) were moving dry air masses over the westcentral African region, and the Intertropical Convergence Zone (ITCZ) was at its minimum latitude over the Equator. This period also coincided with fire peaks in the whole re-
\end{abstract}

gion. On the contrary, $\mathrm{N}$ concentration in gas, aerosol and rain decreased from May to October when prevalent winds arrived from the sea (southeast), during the monsoon period. Both ionic compositions of rain and analysis of local wind direction showed a significant and continuous presence of see breeze at site. The ionic composition of rainwater resulted much closer to seawater and poorer in $\mathrm{N}$ compounds from May to October.

\section{Introduction}

Tropical forests have a key role in terrestrial carbon cycling, acting as the most important global terrestrial $\mathrm{C}$ sink and $\mathrm{C}$ reservoir. They are the most productive ecosystems on earth, having the highest rate of gross primary productivity (GPP) per surface area and accounting for $34 \%$ of the world's GPP (Beer et al., 2010). The total biomass stock of tropical forests is estimated to be around $247 \mathrm{Gt} \mathrm{C}$, of which 49, 25 and $26 \%$ is attributed to Latin America, subSaharan Africa and Southeast Asia, respectively (Saatchi et al., 2011). Although old forest stands are generally considered to be a minor sink compared to the intermediate stage of forest successions, Lewis et al. (2009) have demonstrated that, in Amazonia, old-growth forests have increased their carbon storage over recent decades and have hypothesized that this might be a pan-tropical phenomenon, probably stimulated by the fertilization effect of increased $\mathrm{CO}_{2}$ atmospheric concentration. However, significant evidence exists 
that the $\mathrm{CO}_{2}$ fertilization effect is constrained by $\mathrm{N}$ availability and $\mathrm{N}$ fertilization (Flischer et al., 2013; Reich et al., 2013). A potential external source for $\mathrm{N}$ in forest ecosystems is represented by $\mathrm{N}$ depositions (Dise et al., 1995; Gundersen et al., 1998; Rennenberg et al., 1999; Wolff et al., 2010). The source of $\mathrm{N}$ deposition can be mainly attributed to the combustion of fossil fuels, agricultural practices, animal breeding and fires (Chen et al., 2010; Galloway et al., 1998; Law et al., 2013). The first three sources might account for most of the $\mathrm{N}$ depositions observed in industrialized regions and have been hypothesized to stimulate forest growth and C sequestration in Europe (Magnani et al., 2008). In tropical areas, and particularly in Africa, fires might represent the most relevant atmospheric source of extra $\mathrm{N}$ for downwind forest ecosystems. Fire-induced losses of $\mathrm{N}$ by means of volatilization are substantial (Raison et al., 1985; Cook, 1994; Bustamante et al., 2006). Nitric oxide (NO) and ammonia $\left(\mathrm{NH}_{3}\right)$ are the primary $\mathrm{Nr}$ (reactive $\mathrm{N}$ ) gases emitted from fires, accounting typically for over $90 \%$ of $\mathrm{Nr}$ emissions (Andreae and Merlet, 2001). These gases are converted to other $\mathrm{Nr}$ gases $\left(\mathrm{NO}_{2}, \mathrm{HNO}_{3}\right)$ and to particulate species $\left(\mathrm{NO}_{3}^{-}, \mathrm{NH}_{4}^{+}\right.$, and organic aerosols) by means of multiple reaction pathways (Crutzen and Andreae, 1990; Atkinson, 2000). The significant increase of tropical deforestation rates observed in the last century (Houghton and Hackler, 2006) as well as the increased use of land for animal breeding (FAOSTAT database), most often accompanied by the practice of burning in managed pastures, has most likely increased the input of $\mathrm{Nr}$ in tropical regions. This phenomenon alone or in combination with increased atmospheric concentration of $\mathrm{CO}_{2}$ might have stimulated forest growth. However, little atmospheric concentration data in tropics are available, in particular in the African continent (Martins, 2007; Adon, 2010; Delon, 2012; Sigha, 2003) which might make it possible to quantify $\mathrm{N}$ depositions and to validate and implement chemical-transport model to test the fire hypothesis and to better forecast regional air quality (Elbern et al., 2007; Carmichael et al., 2008; Chen et al., 2010; Curier et al., 2012).

Based on previous simulations of $\mathrm{N}$ deposition by Chen et al. (2010), which supported the concept that a significant amount of $\mathrm{N}$, derived from savanna fires, might be transported equatorward and deposited over tropical forests of the equatorial belt, we set up an experiment in the Ankasa Game Reserve and Nini-Suhien National Park in Ghana, in a rainforest belonging to the western sector of the equatorial African humid forest belt. The work aimed at (1) quantifying the magnitude and seasonal variability of concentrations of $\mathrm{N}$ compounds, which can be detected as gaseous forms and aerosol (dry nitrogen), or can be determined in the rainfall (bulk nitrogen) over the studied forest; (2) relating their seasonal variability to trends of local and regional climatic key variables (winds and rainfalls) which might support the hypothesis of downward atmospheric transport from northern areas; and (3) relating observed variations of dry and bulk nitrogen concentration to variations of fire events in the region.

\section{Materials and methods}

\subsection{Study site}

The study was carried out in the Ankasa Wildlife Protected Area $\left(05^{\circ} 16^{\prime} 11.2^{\prime \prime} \mathrm{N} ; 02^{\circ} 41^{\prime} 41.55^{\prime \prime} \mathrm{W}\right)$ in Ghana, part of a rain forest of about $500 \mathrm{~km}^{2}$ which became a wildlife protection area in 1976. The site is located about $25 \mathrm{~km}$ north of the Guinea coast, slightly north of the Equator in West Africa. This location makes the site highly exposed to seasonal shifts of the Intertropical Convergence Zone (ITCZ), that is the area enclosing the globe where the northeast and southeast trade winds converge, allowing strong atmospheric instability and heavy convective precipitation. The movement of air masses in West Africa is a function of the position of the Intertropical Convergence Zone (ITCZ), which separates the hot and dry continental air coming from the Sahara (the Harmattan) from the cooler, humid maritime air masses (monsoon) originating from the equatorial Atlantic Ocean (Lebel et al., 2009). In summer, the ITCZ moves up to $20^{\circ} \mathrm{N}$ due to southwestern winds, the West African monsoon (WAM, e.g., Thorncroft et al., 2011). This results in several weeks of rainfall in the Sahel region and in the western coasts of northern tropical belt $\left(0^{\circ}-23^{\circ} \mathrm{N} ; 14^{\circ}-18^{\circ} \mathrm{N}\right.$ of Western Africa and $12^{\circ}-16^{\circ} \mathrm{N}$ of Eastern Africa). In winter, the maximum convergence is found just south of the Guinea coastline, forced by a predominant northeasterly wind flow that transports hot and dry air from the arid northern regions towards the western coast of central Africa $\left(0-5^{\circ} \mathrm{N}\right)$ (e.g., Lavaysse et al., 2010). This general synoptic allows a double rain season in Ankasa, with a main peak between April and June and a secondary peak between September and October. The main dry season for the Ankasa area can be considered to last from December until March. The wet season occurs from April until November, with August generally characterized by the lowest monthly rainfall within the wet period. On average the mean annual temperature of the site is about $25^{\circ} \mathrm{C}$ and the mean total annual precipitation is between 1600 and $2000 \mathrm{~mm}$. The relative humidity is high throughout the year, with daily peaks around $90 \%$ at night and $75 \%$ in the early afternoon (Hall and Swaine, 1981).

\subsection{Experimental setup}

Wind data were collected by a Wind-Master Pro sonic anemometer (Gill Instruments Ltd., UK) placed on the tower at $50 \mathrm{~m}$ from soil surface (about $20 \mathrm{~m}$ above the canopy layer), while precipitation was measured at a half-hourly resolution by a rain gauge logged with a CR-1000 logger (Campbell Scientific Inc., Logan, Utah, USA).

In order to quantify dry (gas and aerosol) concentrations a modified DELTA system (DEnuder for Long-Term 
Table 1. Field detection limit, laboratory detection limit and instrumental detection limit for each compound measured using the DELTA system technique.

\begin{tabular}{|c|c|c|c|c|c|c|c|c|c|}
\hline \multirow{2}{*}{$\frac{\text { Detection limit }}{\left(\mathrm{mg} \mathrm{L}^{-1}\right)}$} & \multicolumn{5}{|c|}{ Gas } & \multicolumn{4}{|c|}{ Aerosol } \\
\hline & $\mathrm{NH}_{3}$ & $\mathrm{HCl}$ & $\mathrm{HNO}_{3}$ & $\mathrm{SO}_{2}$ & $\mathrm{NO}_{2}$ & $\mathrm{NH}_{4}^{+}$ & $\mathrm{Cl}^{-}$ & $\mathrm{NO}_{3}^{-}$ & $\mathrm{SO}_{4}^{2-}$ \\
\hline Field blank & 0.37 & 0.17 & 0.21 & 0.22 & 0.19 & 1.16 & 0.86 & 0.13 & 0.10 \\
\hline Laboratory blank & 0.13 & 0.13 & 0.22 & 0.10 & 0.22 & 1.09 & 0.80 & 0.14 & 0.12 \\
\hline Instrumental blank & 0.05 & 0.05 & 0.05 & 0.05 & 0.15 & 0.05 & 0.05 & 0.05 & 0.05 \\
\hline
\end{tabular}

Atmospheric sampling, Sutton et al., 2001) was implemented following the guidelines from the Co-operative Programme for Monitoring and Evaluation of the Long-range Transmission of Air Pollutants in Europe (EMEP, EMEP/CCC-Report $1 / 95$ Revision 1/2001). The system is based on a set of bore glass denuder traps through which a laminar flow of air is driven by a pump (pumping rates are $0.3-0.4 \mathrm{~L} \mathrm{~min}^{-1}$ ) set at the end of the system (Ferm, 1979). A first set of denuders is coated with citric acid to trap ammonia, and a second set is coated with potassium hydroxide to collect acid gases, $\mathrm{HNO}_{3}, \mathrm{SO}_{2}$ and $\mathrm{HCl}$. Aerosols pass through the denuders without reacting and then are collected by a couple of filters placed downstream of the denuders. These filters are treated with the same alkaline (for the collection of the $\mathrm{NH}_{4}^{+}$) and acid (for the collection of $\mathrm{NO}_{3}^{-}, \mathrm{SO}_{4}^{2-}, \mathrm{Cl}^{-}$) solutions as the denuders (Sutton et al., 2001; Tang et al. 2009). In addition, the system has been set for sampling nitrogen dioxide $\left(\mathrm{NO}_{2}\right)$. A method based on the absorption of $\mathrm{NO}_{2}$ on sintered glass impregnated with sodium iodide and sodium hydroxide has been developed by Ferm and Sjodin (1993). $\mathrm{NO}_{2}$ absorbed on the filter is reduced to nitrite $\left(\mathrm{NO}_{2}^{-}\right)$by iodide (EMEP, EMEP/CCC-Report 1/95 Revision 1/2001). The field detection limit, laboratory detection limit and instrumental detection limit for each compound are reported in Table 1. Three DELTA systems were fixed on the tower at $45 \mathrm{~m}$ ( $20 \mathrm{~m}$ above the canopy), each system being protected with a rigid plastic box. Stable sampling rates of $0.38 \mathrm{~L} \mathrm{~min}^{-1}$ were achieved using an air pump with air volumes measured by a gas meter. Each system contains a sampling train made of two denuders for ammonia sampling, two denuders for the gaseous acid sampling, one filter for the aerosol ammonium sampling, one filter for the acid aerosols sampling and two glass filters for the sampling of $\mathrm{NO}_{2}$. The two denuders are set in a series. Not having previous experience with deposition flux rates in the studied forest, the second denuder was added in case high concentrations of atmospheric compounds saturated the first denuder. However, data showed that one denuder was sufficient and that the second denuder usually collected negligible amounts of compounds.

Denuders and filters for field sampling were prepared together with laboratory and field/transport blanks. The laboratory blanks were put in labeled grip seal bags and stored in airtight containers in the laboratory where preparation and analyses are carried out (DISTABIF, Italy). A new set of trains and field/transport blanks was sent monthly in polyethylene grip-seal bags to the study site and exchanged with the old ones, the field/transport blanks were stored inside the enclosure of the DELTA with the new train. Immediately after sampling, the trains were sealed in a polyethylene bag and sent to the laboratory to be analyzed.

To quantify the bulk concentrations, three collectors with a funnel $16 \mathrm{~cm}$ in diameter were continuously exposed for monthly sampling at the same height of the DELTA systems. Biocide (Thymol, 5-methyl-2-[1-methyl]phenol) was added to the collectors to avoid biological alteration of water quality. Every month $100 \mathrm{~mL}$ of sample from each collector were filtered $(0.45 \mu \mathrm{m})$ and transferred into tight plastic bottles for the determination of ion concentrations (EMEP, EMEP/CCC-Report 1/95 Revision 1/2001). Each collector was rinsed three times with deionized water at the end of the sampling period.

The experiment started on 16 October in 2011, and data reported in the paper refer to monthly sampling until 22 October in 2012.

\subsection{Laboratory analyses}

Bulk samples and exposed trains were shipped to DiSTABiF, being stored at $4{ }^{\circ} \mathrm{C}$ until analysis. Acid-coated denuders and aerosols filters were extracted with 3 and $4 \mathrm{~mL}$ of deionized water, respectively, and analyzed for $\mathrm{NH}_{4}^{+}$using ion chromatography (IC) (Dionex DX-120). Carbonate-coated denuders and filters were extracted with $5 \mathrm{~mL}$ of $0.05 \% \mathrm{H}_{2} \mathrm{O}_{2}$ solution followed by analysis of ions $\left(\mathrm{NO}_{3}^{-}, \mathrm{SO}_{4}^{2-}, \mathrm{Cl}^{-}\right)$by IC (Tang et al., 2009). The nitrite formed on the glass filter was extracted with deionized water and triethanolamine and its concentration determined by spectrophotometer (Shimadzu UV-1601, SHIMADZU EUROPA $\mathrm{GmbH}$ ) at $540 \mathrm{~nm}$ by the Griess method (EMEP, EMEP/CCC-Report 1/95 Revision 1/2001). Ion Chromatography was used for the determination of the ions $\left(\mathrm{Cl}^{-}, \mathrm{SO}_{4}^{2-}, \mathrm{NO}_{3}^{-}, \mathrm{Na}^{+}, \mathrm{K}^{+}, \mathrm{Mg}^{2+}\right.$, $\mathrm{Ca}^{2+}$ ) in the bulk collection (EMEP, EMEP/CCC-Report 1/95 Revision 1/2001) using a Dionex DX-120, which is a dual column system that performs isocratic ion analyses using conductivity detection. The dual column system allows switching between two sets of ion exchange resin packing columns (guard columns and analytical columns for both 
anions and cations) and between two eluents. In particular, we used an Ion Pac AS14A and AG14A guard column for anions, an Ion Pac CS14A analytical column and CG14A guard column for cations, $\mathrm{HCO}_{3} / \mathrm{CO}_{3}^{2-} 8 \mathrm{mM}$ buffer and methanesulfonic acid $\left(\mathrm{CH}_{4} \mathrm{O}_{3} \mathrm{~S}\right) 0.02 \mathrm{mM}$ to elute anions and cations, respectively. Two self-regenerating suppressors, positioned after the columns, have the function of neutralizing the eluents and enhancing analyte conductivity (ASRS ultra $4 \mathrm{~mm}$ and CSRS ultra $4 \mathrm{~mm}$ for $\mathrm{HCO}_{3}^{-} / \mathrm{CO}_{3}^{2-}$ and $\mathrm{CH}_{4} \mathrm{O}_{3} \mathrm{~S}$, respectively). A detector cell model CDM-3, used a thermistor for temperature compensation.

\subsection{Data analyses}

Dionex Peaknet 6 software was used to compute ionic concentrations from Ion Chromatography analysis. The concentrations of each compounds was multiplied for the extracted volume and divided for the volume measured by the gas meter to obtain the mean concentrations of each sampling. The amount of a trace gas and aerosol collected $(Q)$ on a denuder and filter due to air sampling is given by

$Q(\mu \mathrm{g})=\left(c_{\mathrm{e}}-c_{\mathrm{b}}\right) \times v$,

where $c_{\mathrm{e}}$ is the liquid concentration of an exposed sample, $c_{\mathrm{b}}$ is the liquid concentration of a blank sample and $v$ is the liquid volume of the extraction solution. The air concentrations $\left(\chi_{\mathrm{a}}\right)$ of the trace gas is then determined as

$\chi_{\mathrm{a}}\left(\mu \mathrm{g} m^{-3}\right)=Q / V$.

$V$ is the volume of air sampled, which is calculated from the gas meter readings.

Wind data were processed using the EddyPro ${ }^{\mathrm{TM}}$ software (LI-COR Inc., Lincoln, NE, USA). In particular, wind vectors were corrected for the angle of attack error (Nakai et al., 2006), rotated (tilt correction) by means of the double rotation method (Wilczak et al., 2001), and screened for the steadiness of horizontal wind (Vickers and Mahrt, 1997).

Meteorological analysis of local and regional data for the period of study was performed using the ERA Interim reanalysis (Berrisford et al., 2009), which provided vertical velocities, meridional and zonal winds. Daily values were filtered through a 30-day running average, in order to filter out the daily noise. Climatic features in the Ankasa location are represented by averaging winds and precipitation over a $1.5^{\circ}$ by $1.5^{\circ}$ area around the coordinates of the site. Precipitation comes from the Tropical Rainfall Measuring Mission (TRMM, Huffman et al., 2007).

Data from Fire Radiative Power (FRP, in MWatts), which provides information on the measured radiant heat output of detected fires (NASA FIRMS, 2012; http://earthdata.nasa. gov/data/near-real-time-data/firms) were analyzed for a region centered in Ankasa, covering an area with a maximum radius of 1000 kilometers, further divided into three concentric areas (0-100, 100-300, 300-1000 km radius). Within

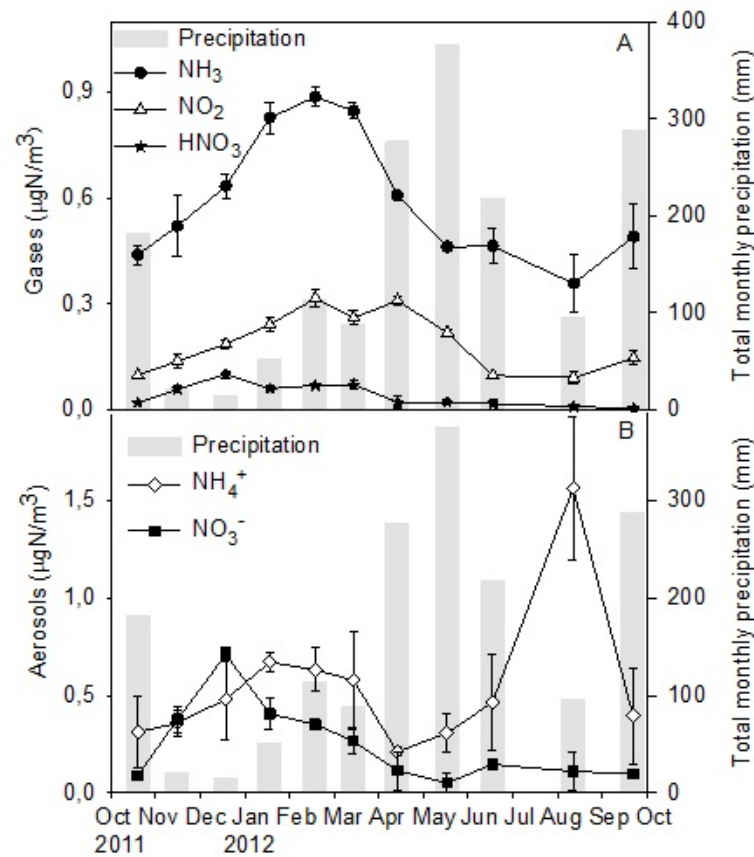

Figure 1. Temporal trends of (A) gaseous $\left(\mathrm{NH}_{3}, \mathrm{NO}_{2}, \mathrm{HNO}_{3}\right)$ and (B) aerosol $\left(\mathrm{NH}_{4}^{+}\right.$and $\left.\mathrm{NO}_{3}^{-}\right)$nitrogen compound concentrations $\left(\mu \mathrm{g} \mathrm{N} \mathrm{m}^{-3}\right.$ ) measured over the Ankasa tower. Bars represent one standard deviation.

each area data for each pixel were first summed to obtain the total MWatts/pixel for each period corresponding to dry and bulk sampling, then the total Mwatts for each area were calculated, summing all the pixels falling into each area. These data were used to represent the temporal trend of fires in the area around Ankasa site at different distances for each sampling period.

\subsection{Statistical analyses}

A one-way analysis of variance (ANOVA) was used to test significant differences among sampling dates for each analyzed compound. When the test was significant an "all pair wise" comparison was carried out based on HolmSidak method. Tests for normality and equal variance were performed before running parametric tests. To measure the strength of the association between pairs of variables, the Pearson product-moment correlation was applied.

\section{Results}

\subsection{Annual trends of dry and bulk concentrations}

The highest values of $\mathrm{NH}_{3}, \mathrm{NO}_{2}$ and $\mathrm{HNO}_{3}$ concentration in the year of sampling were observed from December 2011 to April 2012 (Fig. 1a). The three gases showed a slight shift in the peak of concentration, which occurred from 
Table 2. Concentration of compounds in dry, gases (bold) and aerosols (italic), and bulk sampling (rainfall). In brackets is one standard deviation $(n=3)$. Sampling periods for each cell which start at the date indicated in the column heading and end at the date indicated in the subsequent column.

\begin{tabular}{|c|c|c|c|c|c|c|c|c|c|c|c|}
\hline \multirow[b]{2}{*}{ Date } & \multicolumn{11}{|c|}{ Dry sampling $\left(\mu \mathrm{g} \mathrm{m}^{-3}\right)$} \\
\hline & $16 / 10 / 11$ & $19 / 11 / 11$ & $16 / 12 / 12$ & $18 / 01 / 12$ & $17 / 02 / 12$ & $19 / 03 / 12$ & $14 / 04 / 12$ & $14 / 05 / 12$ & $17 / 06 / 12$ & $18 / 07 / 12$ & $\begin{array}{l}11 / 09 / 12- \\
22 / 10 / 12\end{array}$ \\
\hline $\mathrm{SO}_{2}$ & $0.21(0.00)$ & $0.40(0.03)$ & $0.30(0.05)$ & $0.19(0.03)$ & $0.19(0.02)$ & $0.19(0.04)$ & $0.20(0.03)$ & $0.20(0.03)$ & $0.22(0.00)$ & $0.22(0.00)$ & $0.30(0.00)$ \\
\hline $\mathrm{Cl}^{-}$ & $0.91(0.07)$ & $1.13(0.30)$ & $1.19(0.13)$ & $0.87(0.18)$ & $1.06(0.13)$ & $1.28(0.13)$ & $1.34(0.25)$ & $1.41(0.17)$ & $2.02(0.84)$ & $1.33(0.22)$ & $1.26(0.18)$ \\
\hline $\mathrm{SO}_{4}^{2}$ & $0.48(0.01)$ & $1.10(0.27)$ & $1.66(0.28)$ & $1.39(0.35)$ & $1.05(0.02)$ & $0.83(0.25)$ & $0.68(0.14)$ & $0.80(0.25)$ & $2.01(0.98)$ & $1.45(0.17)$ & $0.94(0.05)$ \\
\hline $\mathrm{Cl}^{-}$ & $2.36(0.55)$ & $3.63(0.62)$ & $3.42(0.51)$ & $4.59(2.65)$ & $10.94(6.82)$ & $3.52(1.95)$ & $1.80(0.31)$ & $1.70(0.55)$ & $30.0(24.0)$ & $18.1(6.3)$ & $9.13(4.61)$ \\
\hline $\mathrm{SO}_{4}^{2-}$ & $0.91(0.18)$ & $1.60(0.20)$ & $2.26(0.23)$ & $1.80(0.89)$ & $3.92(2.00)$ & $1.23(0.55)$ & $0.53(0.06)$ & $0.52(0.13)$ & $9.88(7.34)$ & $4.98(1.52)$ & $2.17(0.83)$ \\
\hline $\mathrm{Na}^{4}$ & $1.60(0.38)$ & $2.40(0.52)$ & $2.38(0.48)$ & $1.90(0.86)$ & $5.31(3.26)$ & $2.90(1.50)$ & $1.51(0.23)$ & $1.39(0.33)$ & $20.3(16.4)$ & $12.6(5.2)$ & $6.50(2.54)$ \\
\hline $\mathrm{K}^{+}$ & $0.31(0.08)$ & $0.73(0.39)$ & $0.70(0.21)$ & $0.52(0.11)$ & $1.88(1.03)$ & $1.17(0.73)$ & $0.26(0.03)$ & $0.21(0.07)$ & $1.77(1.12)$ & $2.39(2.89)$ & $0.90(0.59)$ \\
\hline $\mathrm{Mg}^{2+}$ & $0.15(0.03)$ & $0.25(0.06)$ & $0.32(0.04)$ & $0.59(0.52)$ & $0.84(0.43)$ & $0.28(0.08)$ & $0.14(0.02)$ & $0.12(0.04)$ & $2.26(1.78)$ & $1.10(0.41)$ & $0.52(0.27)$ \\
\hline
\end{tabular}

December 2011 to January 2012 for $\mathrm{HNO}_{3}$, February 2012March 2012 for $\mathrm{NH}_{3}$ and lasted for longer, from February 2012-May 2012, for $\mathrm{NO}_{2}$. This common trend was also reflected by the correlation analysis, which showed a significant correlation of $\mathrm{NH}_{3}$ with $\mathrm{HNO}_{3}(P<0.05, R=0.711)$ and $\mathrm{NO}_{2}(P<0.05, R=0.798)$.

The $\mathrm{NO}_{3}^{-}$concentration in aerosols peaked between December 2011 and January 2012 and was significantly higher in the period between November 2011 and April 2012, compared with October 2011 and the period between April 2012 and October 2012 (Fig. 1b). The temporal trend of aerosol $\mathrm{NO}_{3}^{-}$concentration resembled that of $\mathrm{HNO}_{3}$, as in fact the two variables were significantly correlated $(P<0.05$, $R=0.920$ ). Aerosol $\mathrm{NH}_{4}^{+}$concentration was less variable in time compared with $\mathrm{NO}_{3}^{-}$(Fig. 1b). The amount of $\mathrm{N}$ present in the aerosol in the form of $\mathrm{NO}_{3}^{-}$was generally slightly lower than in the form of $\mathrm{NH}_{4}^{+}$, except at its peak. $\mathrm{NH}_{4}^{+}$concentration in aerosol was quite constant except for a peak in August 2012.

$\mathrm{SO}_{2}$ concentration was generally quite constant, with the exception of the period between November 2011January 2012 and September 2012-October 2012, when concentration increased significantly, almost doubling the values observed during the other months (Table 2). $\mathrm{HCl}$ concentration slightly increased between November 2011 and January 2012 and from June to September, while $\mathrm{Cl}^{-}$concentration in aerosol showed the highest values between April and September 2012 (Table 2). Much more variable was the aerosol concentration of $\mathrm{SO}_{4}^{2-}$ (Table 2).

The mineral nitrogen $\left(\mathrm{NO}_{3}^{-}\right.$and $\left.\mathrm{NH}_{4}^{+}\right)$, measured in the bulk depositions, showed a very high variability between and within sampling events (Fig. 2). Similar to $\mathrm{NO}_{3}^{-}$ measured in aerosol, bulk $\mathrm{NO}_{3}^{-}$concentration peaked be-

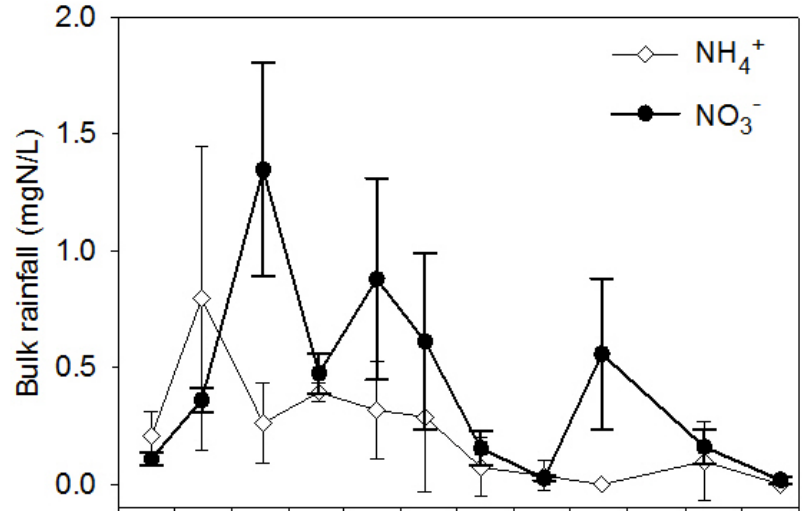

Oct Nov Dec Jan Feb Mar Apr May Jun Jul Aug Sep Oct 20112012

Figure 2. Temporal trends of $\mathrm{NO}_{3}^{-}$and $\mathrm{NH}_{4}^{+}$concentrations in bulk rainfall $\left(\mathrm{mg} \mathrm{N} \mathrm{L}^{-1}\right)$, measured at Ankasa tower. Bars represent one standard deviation.

tween December 2011 and January 2012. As a general trend, the concentration of both ions, $\mathrm{NH}_{4}^{+}$and $\mathrm{NO}_{3}^{-}$, in rainfall increased in the period November-January and decreased afterward (Fig. 2).

The temporal trends of the other bulk compounds $\left(\mathrm{SO}_{4}^{2-}\right.$, $\mathrm{Cl}^{-}, \mathrm{Na}^{+}, \mathrm{Mg}^{2+}, \mathrm{Ca}^{2+}$ ) showed higher concentrations between June and September 2012 (Table 2), with the exception of $\mathrm{K}^{+}$, which reached the highest concentration between November 2011 and April 2012 and from June to September 2012. With the exception of $\mathrm{Na}^{+}$vs. $\mathrm{Ca}^{2+}$ and $\mathrm{Cl}^{-}$vs. $\mathrm{Ca}^{2+}$ the correlation between the different ions measured in rainwater was always significant $(P<0.05)$, the strongest correlation being the one between $\mathrm{Na}^{+}$and $\mathrm{Cl}^{-}(R=0.991$, $P<0.0001)$. The weak correlation between $\mathrm{K}^{+}$vs. $\mathrm{Na}^{+}$, 


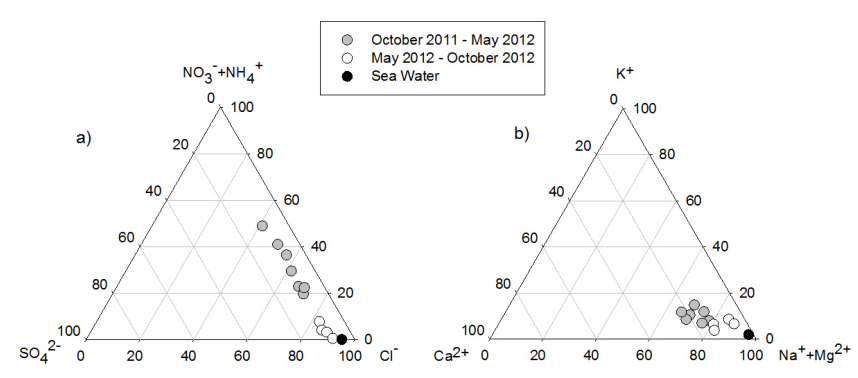

Figure 3. Triangular diagrams of relative ion concentrations $\left(\mathrm{mmol} \mathrm{L}^{-1}\right)$ of (a) $\left.\mathrm{N}-\mathrm{NH}_{4}^{+}+\mathrm{NO}_{3}^{-}\right), \mathrm{SO}_{4}^{-}, \mathrm{Cl}^{-}$, and (b) $\mathrm{K}^{+}, \mathrm{Ca}_{2}^{+}$ and $\mathrm{Na}^{+}+\mathrm{Mg}^{2+}$, measured in the bulk samplings. Data are divided into two periods corresponding to lower (second half of October 2011 to beginning of May 2012) and higher rain intensity (second half May to beginning of October 2012) and typical ionic values for seawater are also reported.

and $\mathrm{K}^{+}$vs. $\mathrm{Cl}^{-}$improved significantly when the data were split into two groups: October 2011-May 2012 ( $R=0.981$ and $R=0.889$, respectively) and May 2012-October 2012 (no significant correlation), which corresponded to sampling during periods characterized by low and high rain regime and different prevailing winds (detailed explanations are given in the next paragraph). The different trends in ionic composition of rainwater in these two distinct periods is well described by the triangular plots of Fig. 3. In the first period, characterized by prevailing air masses coming from $\mathrm{N}-\mathrm{NW}$, higher $\mathrm{NO}_{3}^{-}$ and $\mathrm{NH}_{4}^{+}$concentrations in bulk rainwater were observed and the ionic composition of rainwater was less similar to seawater compared with the second period, when air masses were mainly coming from the ocean and the concentration of $\mathrm{N}$ in rain was lower.

\subsection{Trends of climatic variables and regional fires}

Two scales of observation were used to analyze key drivers of transport and deposition, winds and rainfall: a regional (African continent) and a local (Ankasa) one. In Fig. 4 horizontal winds, at 925 and $850 \mathrm{hPa}$ are reported from October 2011 to November 2012. At $925 \mathrm{hPa}$, winds from the northeast (the Harmattan) prevailed over the whole West African region from December 2011 to January 2012 (Fig. 4). Winds at $850 \mathrm{hPa}$ started to blow from the northeast at Ankasa latitude, already in October-November 2011, reaching the Equator in December 2011-January 2012 and still persisting over the West African region between February and March 2012. In the same period, in particular between November 2011 and March 2012, rainfall was mostly concentrated on the ocean, in front of West African coasts (Fig. 5) over the Equator. A slight anomaly was observed in March 2012, when the strength of the West African monsoon was reduced compared to February and April. For the rest of the analyzed period the rainfall moved northward (Fig. 5) on the continent, driven by the West African monsoon blowing from the ocean from April to October (Fig. 4). The ITCZ reached its most northerly position in August 2012. Hence the shift of ITCZ led to two periods of maximal cloud density at Ankasa latitude, May-July and September-October 2012 (Fig. 5).

Zooming in on the Ankasa level, the TRMM database was used to quantify local precipitation and vertical wind velocity $\left(1.5^{\circ} \times 1.5^{\circ}, 30\right.$-day averaged value $)$, the latter to evidence periods of convection and subsidence activity. Daily values for this year were filtered through a 30-day running mean in order to filter out the daily noise. Precipitations (Fig. 6a) showed a bimodal trend. A main and a secondary rainfall peak occurred in April-July and September-October, respectively, according to the transits of the West African monsoon over the Guinea Coast and to the vertical wind velocity. The vertical wind velocity at $500 \mathrm{hPa}$ was negative during most of the year, denoting uprising air motion associated with convective activity (Fig. 6b). However, from November-March slightly positive (subsidence) values were recorded and from July to September values were close to zero.

The amount of rainwater sampled on the tower (bulk data) was about $30 \%$ higher than data acquired from TRMM data set, although a good correlation was found $(R=0.774$, $P=0.00865$ ) between the two variables. Wind data from the sonic anemometer located on the top of the Ankasa tower showed that, accordingly with TRMM data, the southwest winds prevailed during most of the year, reaching the maximum in July-September (Fig. 7). Northern winds (N, NE and NW) represented only a small percentage of the monthly winds at this observation height and were recorded in October 2011-February 2012 and April-June 2012 (Fig. 7).

The analysis of radiant heat from fires shows that, as expected, maximum values were reached during the drier months (Fig. 8). Fire Radiative Power peaked in December $\left(3.5 \times 10^{6} \mathrm{MW}\right)$ in an area $300-1000 \mathrm{~km}$ away from the Ankasa forest, in February $\left(8 \times 10^{4} \mathrm{MW}\right) 300-100 \mathrm{~km}$ away, and in March $\left(5 \times 10^{3} \mathrm{MW}\right) 100-0 \mathrm{~km}$ away from Ankasa (Fig. 8). The three areas differed not only for the peaking month and the strength of the peak but also for the total radiant heat per square meter, which was $8.4 \mathrm{MW} \mathrm{km}^{-2}$, $2.6 \mathrm{MW} \mathrm{km}^{-2}$ and $1.3 \mathrm{MW} \mathrm{km}^{-2}$ for the areas located 1000 300, 300-100 and 100-0 km away from Ankasa, respectively.

\section{Discussion}

The seasonality of fires and rainfall in the area is related to the fluctuations of the Intertropical Convergence Zone (ITCZ). When the ITCZ reaches its southernmost point (< $5^{\circ} \mathrm{N}$ ), the whole West African region is characterized by a minimum amount of rainfall. In fact, in the period between November 2011 and April 2012, $372 \mathrm{~mm}$ of rainwater were measured in the Ankasa site. In the Lamto site (the wet savanna region of the Ivory Coast, $270 \mathrm{~km} \mathrm{NW}$ from 

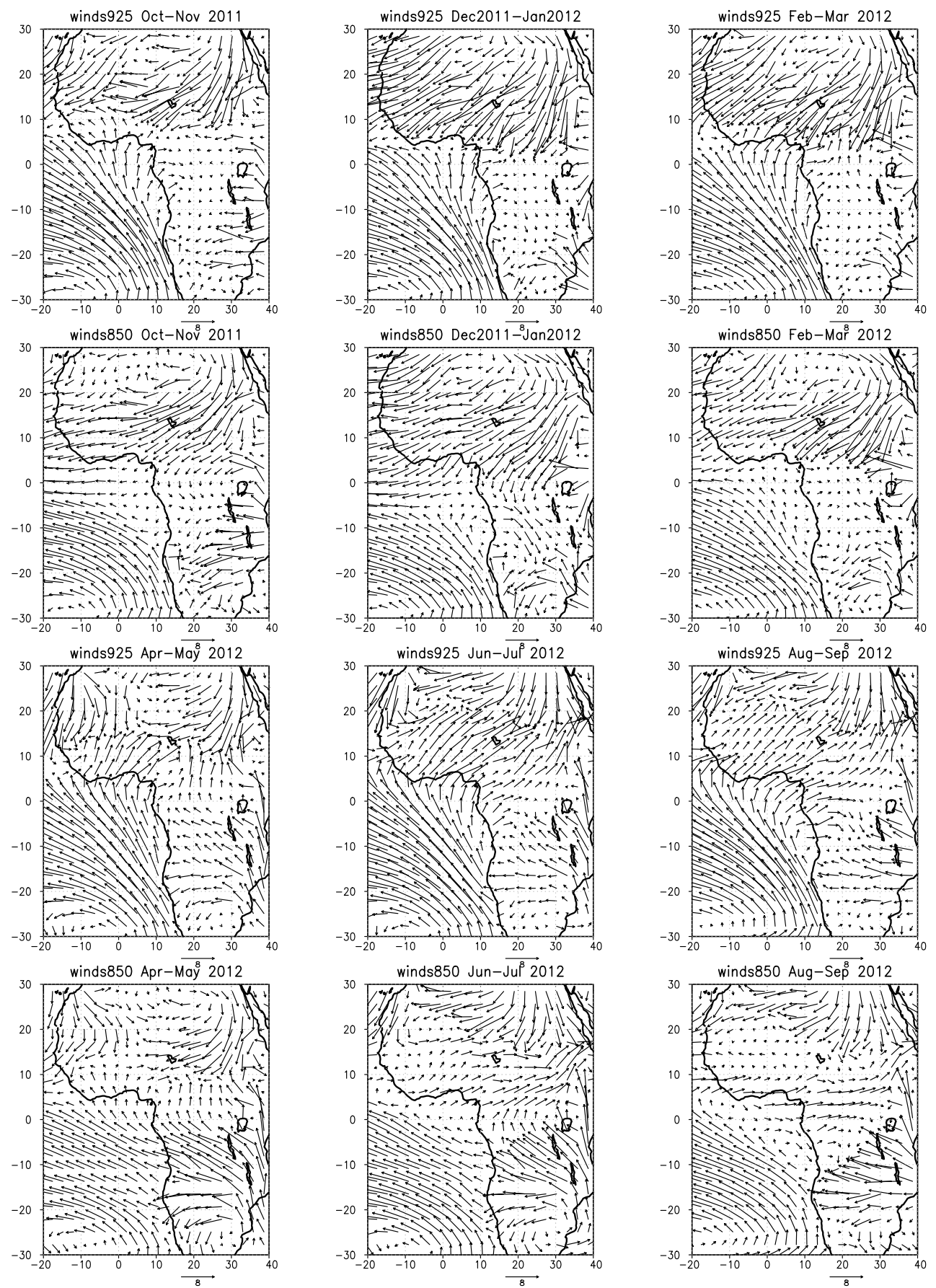

Figure 4. Bimonthly average wind speed and direction at $925,850 \mathrm{hPa}\left(\mathrm{m} \mathrm{s}^{-1}\right)$ calculated over the African continent from October 2011September 2012 from TRMM database.

Ankasa) the mean dry season rainfall reported on average is even lower, at $96 \mathrm{~mm}$ (Yoboué et al., 2005). In the months from April to November 2012 the ITCZ was moving over continental land of the West African region (northward and back), reaching its maximum latitude in August. Over this whole period, when monsoon winds were strongly prevailing at regional scale, $1610 \mathrm{~mm}$ of rainwater were measured at Ankasa. The year 2011-2012 was rather dry in Ankasa, compared with the average of the previous 10 years (TRMM data). The largest negative anomaly was from March to April 2012, at the beginning of the most intense rain period, when precipitation amounts resulted in approximately half the average values reported for the last 10 years (TRMM database). The vertical wind pattern was coherent with this 

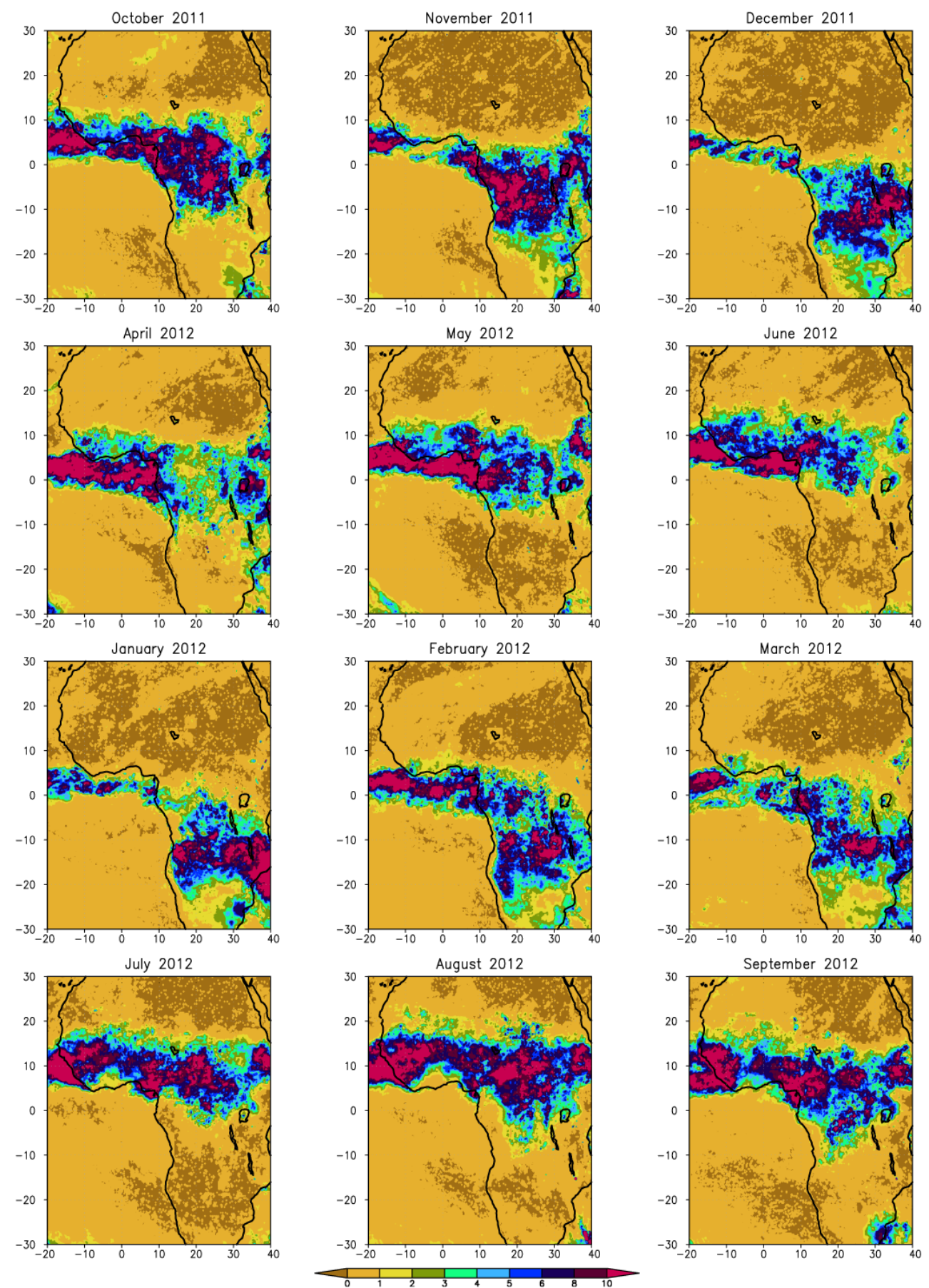

Figure 5. Total monthly precipitation $\left(\mathrm{mm} \mathrm{day}^{-1}\right)$ calculated over the African continent from October 2011 to September 2012 from the TRMM database.

precipitation pattern, including the described anomaly. In fact, vertical wind velocities showed subsidence from December 2011 to March 2012, then fluctuated around zero until May, when convection should have already been triggered (with consequently lower precipitations than expected), and reached a maximum of convection in July, coinciding with the peak of precipitation (Fig. 6a, b). Overall, the weak con- vective activity recorded in year 2012 might be most likely related to the persisting cold anomaly characterizing sea surface temperature (SST) in the southern tropical Atlantic during most of 2012. Evidence has been provided for the existence of a strong correlation between ocean temperature in this region and rainfall in the coast of Guinea (Joly and Voldoire, 2010). 


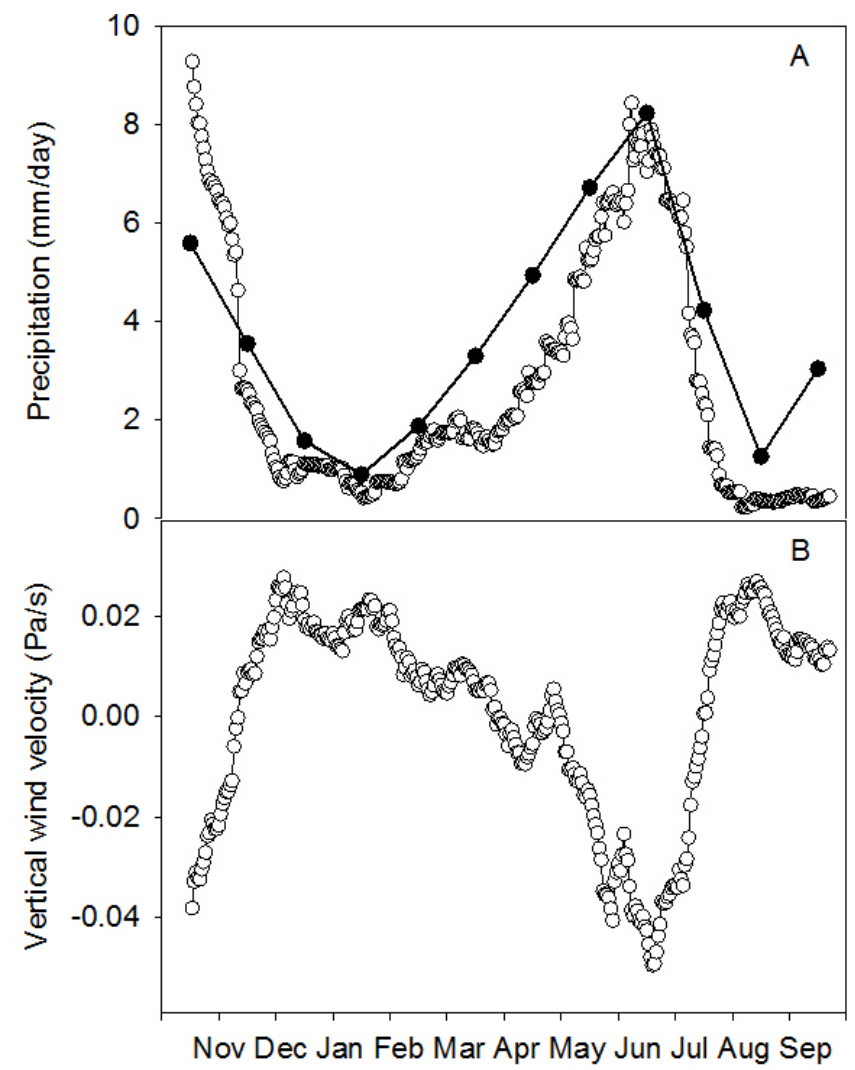

Figure 6. (A) Monthly total precipitation (black circles) from 1998 to 2012 climatology and daily total precipitation (running mean), white circles) for the periods between November 2011 and September 2012, calculated from TRMM database at Ankasa. (B) Vertical velocities at $500 \mathrm{hPa}$ (running mean, positive values indicate subsidence, negative values denote convection) for the periods between November 2011 and September 2012, calculated from the TRMM database at Ankasa.

The period of August 2012 was characterized by a drastic rainfall drop, which corresponded to the period when the ITCZ was in its northernmost position (Figs. 4 and 5); in this period vertical wind velocities at Ankasa indicated air subsidence (Fig. 6b).

The shifting between wet periods during which biomass is produced, and drier periods during which the biomass is turned into highly flammable material, creates conditions for high incidences of fires in the African region, reaching from the sub-Sahara to the Equator. Africa is in fact a firedominated continent, where about $40 \%$ of all fires of the world occur (Koppman, 2005). The most intense fire period in the Northern African hemisphere typically occurs in November-February (Hao and Liu, 1994; Cooke et al, 1996). In accordance, data for the year 2011-2012 showed that fire starting in November 2011 and lasting until February 2012 in the savanna belt were found between 300 and $1000 \mathrm{~km}$ from Ankasa. Closer to Ankasa $(<300 \mathrm{~km})$ both the fire peak and end of the fire season were shifted later in the season. The
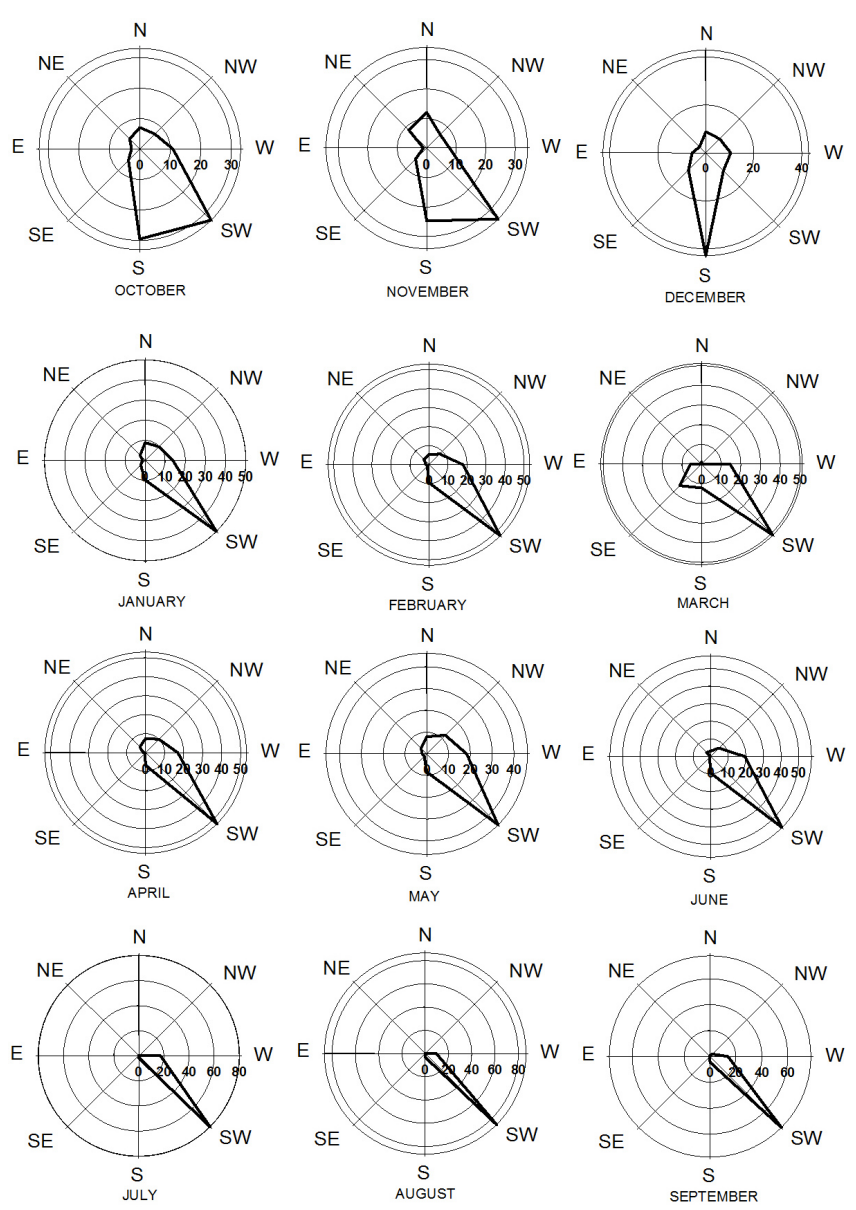

Figure 7. Polar plots of wind direction data, collected by means of a 3-D sonic anemometer placed at $50 \mathrm{~m}$ from the soil $(20 \mathrm{~m}$ above canopy) on the Ankasa tower. Radius units express the percentage contribution of wind data to eight wind direction sectors $\left(45^{\circ}\right.$ each).

overall fire intensity decreased, going from savannas to rain forest areas (Fig. 8), probably due to more humid conditions found southwards, which only allowed for the occurrence of moderate-strength fires.

Galanter et al. (2000) have shown that more than $75 \%$ of the atmospheric $\mathrm{NO}_{\mathrm{x}}$ found in the northern savanna belt of Africa $\left(6^{\circ} \mathrm{N}\right.$ to $\left.15^{\circ} \mathrm{N}\right)$ is the result of biomass burning that occurs from December to February. Although NO is the main product of biomass burning (Andreae and Merlet, 2001), NO can be quickly transformed to $\mathrm{NO}_{2}$ and transported at long distances (Crutzen and Andreae, 1990; Atkinson, 2000). At Ankasa, $\mathrm{NO}_{2}$ concentrations increased from November to April (Fig. 1), corresponding to the whole period of fires occurrence in the Northern African savanna and forest belt (Fig. 8). Two peaks of $\mathrm{NO}_{2}$ concentrations were recorded, one in February and one in April 2012. The first could be explained by fire peaks recorded at a $300-1000 \mathrm{~km}$ distance (December) and at a 300-100 km distance (February) that might have produced $\mathrm{N}$ compounds, the long-range 


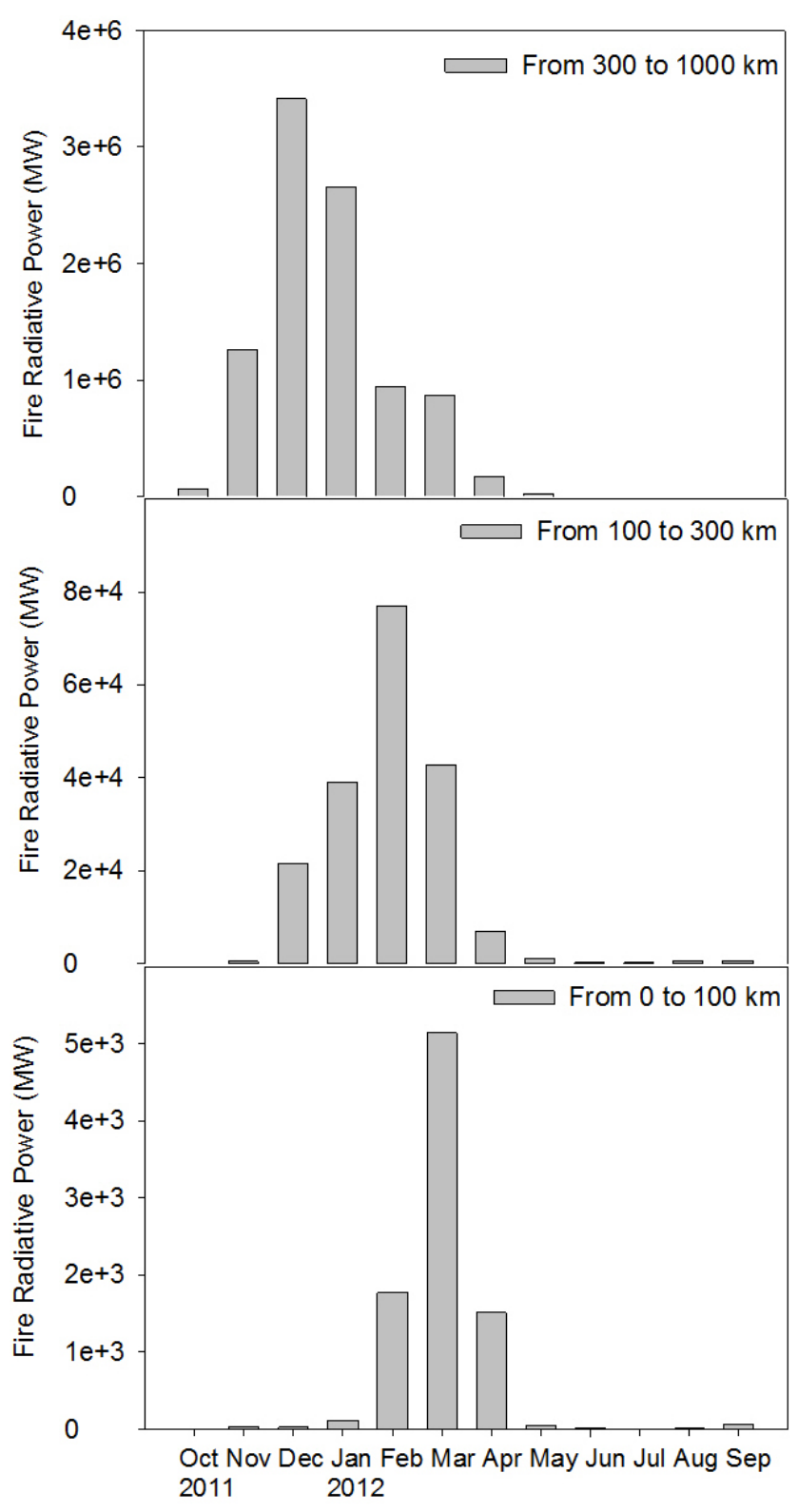

Figure 8. Monthly total Fire Radiative Power calculated for three concentric areas located at a radial distance of 0-100, 100-300, $300-1000 \mathrm{~km}$ from Ankasa, from October 2011 to the end of September 2012.

transport of which might have partially overlapped at lower latitudes (close to Ankasa). The second $\mathrm{NO}_{2}$ peak might instead have coincided with several fire events which were registered near the Ankasa Park in April 2012. The concentration of $\mathrm{NO}_{2}$ measured at Ankasa during the peak of the fire season (Fig. 1) was lower, although in the same order of magnitude, compared with those reported in a rain forest of southern Cameroon $\left(2.1 \mu \mathrm{g} \mathrm{m}^{-3}\right)$ and in a northwest Congolese equatorial forest $\left(3.0 \mu \mathrm{g} \mathrm{m}^{-3}\right)$ during the burning season (Adon et al., 2010). However, the latter values were mea- sured $3 \mathrm{~m}$ from the ground, hence quite close to the soil surface. Tropical forest soil is a significant source of NO (Serca et al., 1994) and the produced NO can be quite quickly oxidized to $\mathrm{NO}_{2}$. Thus it could be expected that the soil source in the Adon et al. (2010) study could more substantially contribute to the total $\mathrm{NO}_{2}$ they collected by passive samplers, compared with $\mathrm{NO}_{2}$ collected in this study $45 \mathrm{~m}$ from the ground, above plant canopy that might capture a large part of $\mathrm{NO}_{2}$ derived from $\mathrm{NO}$ soil emissions (Jacob and Bakwin, 1991; Sparks et al., 2001).

In the period corresponding to the fire season characterized by lower rainfall and a subsidence of air masses at the Ankasa site, higher values of $\mathrm{HNO}_{3}$ and $\mathrm{NO}_{3}^{-}$in aerosols were recorded as well. $\mathrm{HNO}_{3}$ is the result of $\mathrm{NO}_{x}$ oxidation and usually is deposited in a wet or dry form within $24 \mathrm{~h}$ of its formation (Huebert and Robert, 1985), while $\mathrm{NO}_{3}^{-}$particulate formation can be due to the reaction of $\mathrm{HNO}_{3}$ with atmospheric base compounds (Seinfeld and Pandis, 1998). This is in accordance with observed values of $\mathrm{NO}_{3}^{-}$in aerosols, which were significantly correlated with $\mathrm{HNO}_{3}$ concentrations.

Biomass burning (forest, grassland, and agricultural waste) is also a significant source of $\mathrm{SO}_{2}$ to the atmosphere (Bates et al., 1992; Arndt et al., 1997). In fact, values of $\mathrm{SO}_{2}$ concentration at Ankasa site between November and January were twice (up to $0.39 \mu \mathrm{g} \mathrm{m}^{-3}$ ) the amount measured in the wetter months $\left(0.17 \mu \mathrm{g} \mathrm{m}^{-3}\right)$. A comparable increment for both $\mathrm{NO}_{2}$ and $\mathrm{SO}_{2}$ atmospheric concentrations was measured by Campos et al. (2010) using passive sampling in a forest area of the Amazon region, at the onset of the dry and fire season.

Comparable to the other gaseous compounds $\mathrm{NH}_{3}$ concentrations also increased significantly between November 2011 and April 2012 at Ankasa (Fig. 1). $\mathrm{NH}_{3}$ is the primary reactive nitrogen emitted by biomass burning (Andreae and Merlet, 2001). It has a short lifetime in the atmosphere ( $\tau=1-$ 5 days or less) and a relatively high dry deposition velocity, which causes a subsequent substantial fraction (20-40\%) to be deposited not far from its source (Aneja et al., 2001). The statistically significant increase of $\mathrm{NH}_{3}$ concentration at Ankasa, recorded between February and April 2012, coincided with the peak of fire occurrence within an area $300 \mathrm{~km}$ from Ankasa (Fig. 8). These results differed from those reported by Adon et al. (2010) in the equatorial African forests of Zoetele and Bomasa, where no significant difference of $\mathrm{NH}_{3}$ and $\mathrm{NO}_{2}$ concentration was observed between the wet and the dry season; furthermore, the reported concentrations of $\mathrm{NH}_{3}$ were higher than those reported in Ankasa. The latter were also lower than those measured by Rondon and Sanhueza (1990) with active sampling in a woodland savannah in Venezuela (between the Amazon rainforest and the Caribbean Sea) following a biomass burning; however, the opposite is true for $\mathrm{NO}_{3}^{-}$, which was three times higher in the Ankasa site. This difference might also be explained in terms of distance of the fires from the sampling site, since in the 
Venezuelan study fires were closer to the sampling station, which probably favored higher $\mathrm{NH}_{3}$ depositions, while $\mathrm{NO}_{3}^{-}$ in aerosol, which is considered to be a significant component of long-range transported $\mathrm{Nr}$ in the atmosphere (Hertel et al., 2006), might have deposited further from the sampling station in Venezuela.

Taking into account local and regional wind circulation and fire data, we can try to explain most of the temporal variability of $\mathrm{N}$ compound concentrations, observed at Ankasa. Considering a mean wind velocity of about $4 \mathrm{~m} / \mathrm{sec}$, the air masses from different potential sources located $300-1000 \mathrm{~km}$ away from Ankasa would take about 1-3 days to reach the Ankasa tower where, if conditions are favorable, vertical descendant air movements (subsidence) could then deposit the compounds produced during the biomass burning at Ankasa. The winds at $925 \mathrm{hPa}$, which blew from NE in the period November-January, might hence have favored the long-range transport of $\mathrm{HNO}_{3}$ and $\mathrm{NO}_{3}^{-}$generated from fires in the savanna belt, which peaked around December 2011. As the peak of the Fire Radiative Power came closer to Ankasa, $\mathrm{NH}_{3}$ concentrations also started to rise, which corresponded to the period February-April 2012. The 2012 anomaly that created drier conditions in March-April, allowed for a prolonged fire season in the area close to Ankasa (Fig. 8), most probably leading to a second peak of $\mathrm{NO}_{2}$ in April and high values of $\mathrm{NH}_{3}$ concentration still observed in April.

The analysis of regional and, most of all, of local winds showed that a significant component of winds coming from S-SE was always present at Ankasa. This effect can be likely attributed to the presence of sea breezes, long recognized to be an active feature along the Gulf of Guinea coast (Cautenet et al., 1989). The frequency of occurrence of sea breezes shows two regimes characterized by a main peak in the winter and a secondary maximum in May, strongly interacting with the two phases of West African monsoon regime (Gbambie and Stein, 2012). Sea breezes mainly affect the lower atmosphere layers, thus counteracting NE winds at $925 \mathrm{hPa}$, which prevail only in December-January at this height. The important role of see breeze at the Ankasa site was confirmed by the analyses of ions in rainwater, as in fact, a constant presence of ions with a clear marine origin (Yobouè et al., 2005), such as chloride or sodium, was recorded. The ionic composition of the rainfall (Fig. 3) showed that during the monsoon period, when air masses coming from the ocean brought strong rainfall, the ionic concentration was closer to the composition found in marine water and the amount of nitrogen compounds was minimal, whereas the opposite was true during the drier season (Lobert et al., 1990; Delmas et al., 1995; Brocard et al., 1996). The continuous influence of sea-breezes at Ankasa on aerosol concentrations might in part explain the much higher values of peak concentrations of $\mathrm{NO}_{3}^{-}$and $\mathrm{NH}_{4}^{+}$measured at Ankasa, compared with those recorded by Sigha (2003) in the equatorial forest of Zoetele, which is located much further from the sea compared with Ankasa. However, the dif- ference in observed results might also in part be due to the different collection technique (wet deposition at Zoetele and bulk deposition at Ankasa).

\section{Conclusions}

Although a direct proof of $\mathrm{N}$ origin cannot be provided, this study shows that there is a clear seasonality in the atmospheric concentration of $\mathrm{N}$ compounds over this West African rainforest, which is coherent with the dynamics of local and regional meteorological drivers and fire occurrences. The analyses of the whole data set supports the hypothesis that fires from the savannah belt might represent a source of $\mathrm{N}$ for tropical rain forests located in a southern position, thanks to the regional wind circulation. Focusing on the mean annual values of nitrogen compounds, the major contribution on the nitrogen concentrations is given by $\mathrm{NH}_{3}$ $\left(0.594 \mu \mathrm{g} \mathrm{N} \mathrm{m}^{-3}\right)$ and $\mathrm{NH}_{4}^{+}\left(0.543 \mu \mathrm{g} \mathrm{N} \mathrm{m}^{-3}\right)$, followed by $\mathrm{NO}_{3}^{-}\left(0.247 \mu \mathrm{g} \mathrm{N} \mathrm{m}^{-3}\right), \mathrm{NO}_{2}\left(0.190 \mu \mathrm{g} \mathrm{N} \mathrm{m}^{-3}\right)$ and $\mathrm{HNO}_{3}$ $\left(0.040 \mu \mathrm{g} \mathrm{N} \mathrm{m}^{-3}\right)$. The next step to understand the potential impact of this phenomenon on forest productivity is to quantify the magnitude of annual $\mathrm{N}$ deposition fluxes.

Acknowledgements. The present work was supported by the ERC grant GHG Africa no. 247349. We thank Justice John Mensah, Paolo Stefani and Giuseppe Fattore for technical support. We acknowledge the use of FIRMS data and imagery from the Land Atmosphere Near-real time Capability for EOS (LANCE) system operated by the NASA/GSFC/Earth Science Data and Information System (ESDIS) with funding provided by NASA/HQ.

Edited by: X. Wang

\section{References}

Adon, M., Galy-Lacaux, C., Yobouè, V., Delon, C., Lacaux, J.P., Castera, P., Gardrat, E., Pienaar, J., Al Ourabi, H., Laouali, D., Diop, B., Sigha-Nkamdjou, L., Akpo, A., Tathy., J.P., Lavenu, F., and Mougin, E.: Long term measurements of sulfur dioxide, nitrogen dioxide, ammonia, nitric acid and ozone in Africa using passive samplers, Atmos. Chem. Phys., 10, 7467-7487, doi:10.5194/acp-10-7467-2010, 2010.

Andreae, M. and Merlet, P.: Emission of trace gases and aerosols from biomass burning, Global Biogeochem. Cy., 15, 955-966, 2001.

Aneja, V. P., Roelle, P. A., Murray, G. C., Southerland, J., Erisman, J. W., Fowler, D., Asman, W. A. H., and Patni, N.: Atmospheric nitrogen compounds II: emissions, transport, transformation, deposition and assessment, Atmos. Environ., 35, 1903-1911, 2001.

Arndt, R., Carmichael, G. R., Streets, D. G., and Bhatti, N.: Sulfur dioxide emissions and sectorial contributions to sulfur deposition in Asia, Atmos. Environ., 31, 1553-1572, 1997.

Atkinson, R.: Atmospheric chemistry of VOCs and NOx, Atmospheric Environment, 34, 2063-2101, 2000. 
Bates, T. S., Lamb, B. K., Guenther, A., Dignon, J., and Stoiber, R. E.: Sulfur emissions to the atmosphere from natural sources, J. Atmos. Chem., 14, 315-317, 1992.

Beer, C., Reichstein, M., Tomelleri, E., Ciais, P., Jung, M., Carvalhais, N., Rödenbeck, C., Arain, M. A., Baldocchi, D., Bonan, G. B., Bondeau, A., Cescatti, A., Lasslop, G., Lindroth, A., Lomas, M., Luyssaert, S., Margolis, H., Oleson, K. W., Roupsard, O., Veenendaal, E., Viovy, N., Williams, C., Woodward, F. I., and Papale, D.: Terrestrial Gross Carbon Dioxide Uptake: Global Distribution and Covariation with Climate, Science, 329, 834-838, 2010.

Berrisford, P., Dee, D. P., Fielding, K., Fuentes, M., Kållberg, P., Kobayashi, S., and Uppala, S. M.: 'The ERA-Interim Archive', ERA Report Series, No. 1. ECMWF, Reading, UK, 2009.

Brocard, D., Lacaux C., Lacaux, J. P., Kouadio, G., and Yobouè, V.: Emissions from the combustion of biofuels in western Africa, in: Global Biomass Burning, edited by: Levine, J. S., MIT Press, Cambridge, 492-508, 1996.

Bustamante, M. M. C., Medina, E., Asner, G. P., Nardoto, G. B., and Garcia-Montiel D. C.: Nitrogen cycling in tropical and temperate savanna, Biogeochemistry, 79, 209-237, 2006.

Campos, V. P., Cruz, L. P. S., Godoi, R. H. M., Godoi, A. F. L., and Tavares, T. M.: Development and validation of passive samplers for atmospheric monitoring of $\mathrm{SO}_{2}, \mathrm{O}_{3}$ and $\mathrm{H}_{2} \mathrm{~S}$ in tropical areas, Microchem. J., 96, 132-138, 2010.

Carmichael, G., Sandu, A., Chai, T., Daescu, D., Constantinescu, E., and Tang, Y.: Predicting air quality: improvements through advanced methods to integrate models and measurements, J. Comput. Phys., 227, 3540-3571, 2008.

Cautenet, S. and Rosset, R.: Numerical simulation of sea breezes with vertical wind shear during dry season at Cape of Three Points, West Africa, Monthly Weather Rev., 117, 329-339, 1989.

Chen, Y., Randerson, J. T., van der Werf, G. R., Morton D. C., Mu, M., and Kasibhatlas, P. S.: Nitrogen deposition in tropical forests from savanna and deforestation fires, Global Change Biol., 16, 2024-2038, 2010.

Cook, G. D.: The fate of nutrients during fires in a tropical savanna, Austr. J. Ecol., 19, 359-365, 1994

Cooke, W. F., Koffi, B., and Gregoire, J.-M.: Seasonality of vegetation fires in Africa from remote sensing data and application to a global chemistry model, J. Geophys. Res., 101, 21051-21065, 1996.

Crutzen, P. J. and Andreae M. O.: Biomass burning in the tropics - impact on atmospheric chemistry and biogeochemical cycles, Science, 250, 1669-1678, 1990.

Curier, R. L., Timmermans, R., Calabretta-Jongen, S., Eskes, H., Segers, A., Swart, D., and Schaap, M.: Improving ozone forecasts over Europe by synergistic use of the LOTOS-EUROS chemical transport model and in-situ measurements, Atmos. Environ., 60, 217-226, 2012.

Delmas, R., Lacaux, J. P., Menaut, J. C., Abbadie, L., Leroux, X., Helas, G., and Lobert, J.: Nitrogen compound emission from biomass burning in tropical African savanna, FOS/DECAFEExperiment, J. Atmos. Chem., 22, 175-194, 1995.

Delon, C., Galy-Lacaux, C., Boone, A., Liousse, C., Serça, D., Adon, M., Diop, B., Akpo, A., Lavenu, F., Mougin, E., and Timouk, F.: Atmospheric nitrogen budget in Sahelian dry savannas, Atmos. Chem. Phys., 10, 2691-2708, doi:10.5194/acp-10-26912010, 2010 .
Dise, N. B. and Wright, R. F.: Nitrogen leaching from European forests in relation to nitrogen deposition, Forest Ecol. Manage., 71, 153-161, 1995.

Elbern, H., Strunk, A., Schmidt, H., and Talagrand, O.: Emission rate and chemical state estimation by 4-dimensional variational inversion, Atmos. Chem. Phys., 7, 3749-3769, doi:10.5194/acp7-3749-2007, 2007.

Ferm, M.: Method for determination of atmospheric ammonia, Atmos. Environ., 13, 1385-1393, 1979.

Ferm, M. and Sjödin, $\AA$.: Proposal of an impregnated filter technique for monitoring of $\mathrm{NO}_{2}$ at EMEP stations, in: EMEP Workshop on measurements of nitrogen-containing compounds, Ballman, R., Les Diablerets, Switzerland, 173-181, 1993.

Flischer, K., Rebel, K. T., van der Molen, M. K., Erisman, J. W., Wassen, M. J., van Loon, E. E., Montagnani, L., Gough, G. M., Herbst, M., Janssens, I. A., Gianelle, D., and Dolman, A. J.: The contribution of nitrogen deposition to the photosynthetic capacity of forests, Global Biogeochem. Cy., 27, 187-199, 2013.

Galanter, M., Levy II, H., and Carmichael, G. R.: Impacts of biomass burning on tropospheric $\mathrm{CO}, \mathrm{NO}_{\mathrm{x}}$, and $\mathrm{O}_{3}$, J. Geophys. Res., 105, 6633-6653, 2000.

Galloway, J. N.: The global nitrogen cycle: changes and consequences, Environ. Pollut., 102, 15-24, 1998.

Gbambie, A. S. B. and Steyn, D. G.: Sea breezes at Cotonou and their interaction with the West African monsoon, Int. J. Climatol., 33, 2889-2899, doi:10.1002/joc.3637, 2012.

Gundersen, P., Emmet, B. A., Kionaas, O. J., Koopmans C. J., and Tietema A.: Impact of nitrogen deposition on nitrogen cycling in forests: a synthesis of NITREX data, Forest Ecol. Manage., 101, 37-55, 1998

Hall, J. B. and Swaine, M. D.: What is forest, in: Distribution and Ecology of Vascular Plants in a Tropical Rain Forest, Forest Vegetation in Ghana, edited by: Junk, W., The Hague, The Netherlands, 3-29, 1981.

Hao, W. M. and Liu, M.-H.: Spatial and temporal distribution of tropical biomass burning, Global Biogeochem. Cy., 8, 495-503, 1994.

Hertel, O., Skjoth, C. A., Lofstrom, P., Geels, C., Frohn, L. M., Ellermann, T., and Madsen, P. V.: Modelling nitrogen deposition on a local scale - A review of the current state of the art, Environ. Chem., 3, 317-337, 2006.

Houghton, R. A. and Hackler, J. L.: Emissions of carbon from land use change in sub-Saharan Africa, J. Geophys. Res., 111, G02003, doi:10.1029/2005JG000076, 2006.

Huebert, B. J. and Robert, C. H.: The dry deposition of nitric-acid to grass, J. Geophys. Res., 90, 2085-2090, 1985.

Huffman, G. J., Adler, R. F., Bolvin, D. T., Gu, G., Nelkin, E. J., Bowman, K. P., Hong, Y., Stocker, E. F., and Wolff, D. B.: The TRMM Multisatellite Precipitation Analysis (TMPA): QuasiGlobal, Multiyear, Combined-Sensor Precipitation Estimates at Fine Scales, J. Hydrometeor, 8, 38-55, 2007.

Jacob, D. J. and Bakwin, P. S.: Cycling of $\mathrm{NO}_{\mathrm{x}}$ in tropical forest canopies and its implications for the global source of biogenic NOx to the atmosphere, in: Microbial Production and Consumption of Greenhouse Gases, edited by: Whitman, W. B., American Society of Microbiology, Washington DC, 1991.

Joly, M. and Voldoire, A.: Role of the Gulf of Guinea in the interannual variability of the West African monsoon: what do we 
learn from CMIP3 coupled simulations?, Int. J. Climatol., 30, 1843-1856, 2010.

Koppmann, R., von Czapiewski, K., and Reid, J. S.: A review of biomass burning emissions - Part I: gaseous emissions of carbon monoxide, methane, volatile organic compounds, and nitrogen containing compounds, Atmos. Chem. Phys. Discuss., 5, 1045510516, doi:10.5194/acpd-5-10455-2005, 2005.

Lavaysse, C., Flamant, C., and Janicot, S.: Regional-scale convection patterns during strong and weak phases of the Saharan heat low, Atmosph. Sci. Lett., 11, 255-264, 2010.

Law, B.: Biogeochemistry: Nitrogen deposition and forest carbon, Nature, 496, 307-308, 2013.

Lebel, T. and Ali, A.: Recent trends in the Central and Western Sahel rainfall regime (1990-2007), J.Hydrol., 375, 52-64, 2009.

Lewis, S. L., Lopez-Gonzalez, G., Sonké, B., Affum-Baffoe, K., Baker, T. R., Ojo, L. O., Phillips, O. L., Reitsma, J. M., White, L., Comiskey, J. A., Djuikouo, K. M. N., Ewango, C. E., Feldpausch, T. R., Hamilton, A. C., Gloor, M., Hart, T., Hladik, A., Lloyd. J., Lovett, J. C., Makana, J. R., Malhi, Y., Mbago, F. M., Ndangalasi, H. J., Peacock, J., Peh, K. S., Sheil, D., Sunderland, T., Swaine, M. D., Taplin, J., Taylor, D., Thomas, S. C., Votere, R., and Wöll, H.: Increasing carbon storage in intact African tropical forests, Nature, 457, 1003-1006, 2009.

Lobert, J. M., Scharffe, D. H., Hao, W. M., and Crutzen, P. J.: Importance of biomass burning in the atmospheric budgets of nitrogen containing gases, Nature, 346, 552-554, 1990.

Magnani, F., Mencuccini, M., Borghetti, M., Berbigier, P., Berninger, F., Delzon, S., Grelle, A., Hari, P., Jarvis, P. G., Kolari, P., Kowalski, A. S., Lankreijer, H., Law, B.E., Lindroth, A., Loustau, D., Manca, G., Moncrieff, J. B., Rayment, M., Tedeschi, V., Valentini, R., and Grace, J.: The human footprint in the carbon cycle of temperate and boreal forests, Nature, 447, 849-851, 2007.

Martins, J. J., Dhammapala, R. S., Lachmann, G., Galy-Lacaux, C., and Pienaar, J. J.: Long-term measurements of sulphur dioxide, nitrogen dioxide, ammonia, nitric acid and ozone in southern Africa using passive samplers, S. Afr. J. Sci., 103, 336-342, 2007.

Nakai, T., van der Molen, M. K., Gash, J. H. C., and Kodama, Y.: Correction of sonic anemometerangle of attack errors, Agr. Forest Meteorol., 136, 19-30, 2006.

NASA FIRMS: MODIS Hotspot / Active Fire Detections, Data set, available at: http://earthdata.nasa.gov/firms, 2012.

Raison, R. J., Khanna, P. K., and Woods, P. V.: Mechanisms of element transfer to the atmosphere during vegetation fires, Can. J. Forest Res., 15, 132-140, 1985.

Reich, P. B. and Hobbie, S. E.: Decade-long soil nitrogen constraint on the $\mathrm{CO}_{2}$ fertilization of plant biomass, Nature Clim. Change, 3, 278-282, 2013.

Rennenberg, H. and Gessler, A.: Consequences of $\mathrm{N}$ deposition to forest ecosystems, recent results and future research needs, Water Air Soil Pollut., 116, 47-64, 1999.
Rondon, A. and Sanhueza, E.: Seasonal variation of gaseous $\mathrm{HNO}_{3}$ and $\mathrm{NH}_{3}$ at a tropical savannah site, J. Atmos. Chem., 11, 245254, 1990.

Saatchi, S. S., Harris, N. L., Brown, S., Lefsky, M., Mitchard, E. T. A., Salas, W., Zutta, B. R., Buermann, W., Lewis, S. L., Hagen, S., Petrova, S., White, L., Silman, M., and Morel, A.: Benchmark map of forest carbon stocks in tropical regions across three continents, PNAS, 108, 9899-9904, 2011.

Seinfeld, J. H. and Pandis, S. N.: Atmospheric Chemistry and Physics, New York, John Wiley \& Sons, Inc., 1998.

Serca, D., Delmas, R., Jamnert, C., and Labroue, L.: Emissions of nitrogen oxides from equatorial rain forest in central Africa: origin and regulation of NO emission from soils, Tellus, 46B, 243254, 1994.

Sigha-Nkamdjou, L., Galy-Lacaux, C., Pont, V., Richard, S., Sighoumnou, D., and Lacaux, J. P.: Rainwater chemistry and wet deposition over the equatorial forested ecosystem of Zoétélé (Cameroon), J. Atmos. Chem., 46, 173-198, 2003.

Sparks, J. P., Monson, R. K., Sparks, K. L., and Lerdau, M.: Leaf uptake of nitrogen dioxide $\left(\mathrm{NO}_{2}\right)$ in a tropical wet forest: implications for tropospheric chemistry, Oecologia, 127, 214-221, 2001.

Sutton, M. A., Tang, Y. S., Miners, B., and Fowler, D.: A new diffusion denuder system for long-term, regional monitoring of atmospheric ammonia and ammonium, Water, Air Soil Pollut. Focus, 1, 145-156, 2001.

Tang, Y. S., Simmons, I., van Dijk, N., Di Marco, C., Nemitz, E., Dammgen, U., Gilke, K., Djuricic, V., Vidic, S., Gliha, Z., Borovecki, D., Mitosinkova, M., Hanssen, J. E., Uggerud, T. H., Sanz, M. J., Sanz, P., Chorda, J. V., Flechard, C. R., Fauvel, Y., Ferm, M., Perrino, C., and Sutton, M. A.: European scale application of atmospheric reactive nitrogen measurements in a lowcost approach to infer dry deposition fluxes, Agriculture, Ecosys. Environ., 133, 183-195, 2009.

Thorncroft, C. D., Nguyen, H., Zhang, C., and Peyrillé, P.: Annual cycle of the West African monsoon: regional circulations and associated water vapour transport, Q. J. R. Meteorol. Soc., 137, 129-147, 2011.

Vickers, D. and Mahrt, L.: Quality control and flux sampling problems for tower and aircraft data, J. Atmos. Oc. Technol., 14, 512526, 1997.

Wilczak, J. M., Oncley, S. P., and Stage, S. A.: Sonic anemometer tilt correction algorithms, Bound.-Layer Meteorol., 99, 127-150, 2001.

Wolff, V., Trebs, I., Foken, T., and Meixner, F. X.: Exchange of reactive nitrogen compounds: concentrations and fluxes of total ammonium and total nitrate above a spruce canopy, Biogeosciences, 7, 1729-1744, doi:10.5194/bg-7-1729-2010, 2010.

Yoboué, C., Galy-Lacaux, C., Lacaux, J. P., and Siluè, S.: Rainwater chemistry and wet deposition over the Wet Savanna Ecosystem of Lamto (Cote d'Ivoire), J. Atmos. Chem., 52, 117-141, 2005. 